\title{
The Teacher's Critical Thinking Skills in Solving Mathematical Problems
}

\author{
Nonik Indrawatiningsih', Abdur Rahman As'ari², Luthfi Hakim ${ }^{3}$ \\ ${ }^{I}$ Mathematics Education, Universitas PGRI WIRANEGARA Pasuruan \\ Pasuruan, Indonesia \\ E-mail: nonikPhy.D@gmail.com \\ ${ }^{2}$ Mathematics Education, Universitas Negeri Malang \\ Jl. Semarang No. 5 Malang, Jawa Timur, Indonesia \\ E-mail: abdur.rahman.fmipa@um.ac.id \\ ${ }^{3}$ Mechanical Engineering, Majapahit Islamic University \\ Mojokerto, Indonesia \\ E-mail: hakimunim@gmail.com
}

\begin{abstract}
This study to describe the critical thinking skills of master students who are high school / high school / MA teachers being studied. This type of research is a descriptive study with a qualitative approach. Data was collected from the results of critical thinking skills tests and interviews. Furthermore, the data collected were analyzed based on indicators of critical thinking capacity determined by researchers which included interpretation, analysis, evaluation, inference and explanation. The subjects of this study were 2 people who were considered potential researchers to have critical thinking skills. This can be seen when attending lectures and observing learning in the classroom. Based on the results of the analysis of the results of interviews and interview results subject 1 has the capacity to think critically better than on subject 2 . Subject 1 can achieve five indicators of capacity for critical thinking, while subject 2 only on 3 indicators: interpretation, analysis and evaluation. On the inference and explanation indicators, subjects 2 are not fulfilled. This is because subject 2 only looks at solving problems from one angle without paying attention to other perspectives, which in the end will be able to draw some conclusions.
\end{abstract}

Keywords: Critical Thinking Skills; Solving Mathematical Problems.

\section{Introduction}

The 2013 curriculum is a refinement of the 2006 curriculum. In the curriculum, one of the basic competencies students must develop is critical thinking [1]. Critical thinking skills are the goal of developing educational curricula around the world [2] [3]. The flow of mathematics education reform throughout the world includes the transition from algorithmic cognitive abilities towards critical thinking skills [4].

The main assumption behind the successful implementation of such a curriculum is the teacher. The teachers are required to have the knowledge and capacity to teach critical thinking skills to students (students) as stated in the education policy. Therefore, the Indonesian government provides a scholarship program for teachers to continue their education to the Masters level (S2). With the hope of increasing qualifications as a teacher, teachers must encourage the growth and development of students' critical thinking abilities and dispositions.

Minister of National Education Regulation Number 22 Year 2006 regarding Content Standards states that "mathematics subjects need to be given to all students starting from elementary school to equip them to think logically, analytically, systematically, critically and creatively" [5]. This is in line with the mathematics content competencies listed in Article 21 of the Ministry of Education and Culture Regulation 21 at the basic education level (Class VII-IX) which states that students 
are expected to be able to show logical, critical, analytical, careful and conscientious, responsible, responsive, and not easy to give up in solving problems [6] .

Understanding of critical thinking has been widely defined by several experts [7] [8] [9] [10] [11]. The most basic concepts of critical thinking skills are Interpretation, Analysis, Evaluation, Inference, Explanation and Self-regulation [7] [8]. Critical thinking as "reflective thinking that makes sense and focuses on making decisions what to believe or what to do" [9]. People who think critically always challenge, analyze, and assess the truth of the information so that its truth can be maintained and accounted for [10]. Likewise, critical thinking is very necessary for students to use new information or manipulate existing knowledge and information to obtain responses that make sense for new situations [11] [12] [13].

In the context of mathematical problem solving, Krulik and Rudnick (1995) state that critical thinking is analytical thinking and reflection that involves testing activities, questioning, connecting and evaluating all aspects of a situation or problem . The ability to think critically is very important in learning mathematics, because this ability can improve the quality of learning mathematics that is better and meaningful through learning mathematics in schools [14].

Critical thinking learning strategies are active processes in improving student performance in school. Listening to lectures in class, for most students is a passive activity because students only listen and will not have the opportunity to ask questions when the learning process takes place and this makes the class boring. Critical thinking skills such as analysis, synthesis, reflection, etc. must be learned by students. Therefore, the teacher must emphasize the active intellectuals of students in teaching mathematics. Mathematics as an important subject in today's modern society and is useful in schools, workplaces in decision making. Mathematics is seen as a language for daily use both in the market, school or even at home. Mathematics is the basis for national prosperity in providing tools for understanding Science, Engineering, Technology and Economics [15]. The importance of this may have caused the Indonesian government to include a critical thinking component in the 2013 curriculum which must be applied by teachers in teaching in schools.

The ability to think critically in mathematics is a process of critical thinking related to mathematical knowledge, mathematical reasoning and mathematical evidence on mathematical problem solving [16], [17]. Therefore, before the teacher practices students' critical thinking skills in the classroom. The teacher should have the ability to think critically first. In this study, researchers wanted to describe the critical thinking skills of high school / vocational / MA teachers who were pursuing postgraduate education at a state tertiary university in Malang. To assess this critical thinking ability using five indicators, namely (1) Interpretation, (2) Analysis, (3) Evaluation, (4) Inference and (5) Explanation.

\section{Methods}

This type of research is a qualitative descriptive study. The subjects of the study were S2 Mathematics Education students at one of the State Universities in Malang in 2017, where these students were vocational / high school / MA teachers who were pursuing further S2 studies. Research subjects numbered 2 people taken as respondents who have the potential to think critically during the learning process in class.

The subject selection by the researcher is based on observations while the researcher follows the learning process activities that are taking place in class. The indicators of critical thinking ability that are measured are as follows: (1) Interpretation, (2) Analysis, (3) Evaluation, (4) Inference and (5) Explanation. [7]

In order to obtain valid data, researchers conducted semi-structured interviews with questions that focused on critical thinking skills in solving mathematical problems which included 5 indicators of critical thinking skills. The interview is conducted for 20-30 minutes. The interview results are recorded and then transcribed and coded. The following are the forms of the test questions given to the subject. From the results of written tests and interviews, further analyzed and used to support the process of describing students' critical thinking skills by researchers.

\section{Result and Discussion}

Based on the data on the results of critical thinking skills tests and interviews, subject 1 fulfills all 5 indicators of critical thinking skills. Whereas subject 2 fulfills 3 indicators of critical thinking ability.

The following will explain the subject's critical thinking skills based on indicators of critical thinking skills. 


\subsection{Interpretation (interpretation)}

The interpretation intended in this study is how the subject responds when facing a mathematical problem in the form of a problem. Is it answered directly or first time observing the problem and reviewing the information in question. From the results of the written test, subject 1 wrote "the questions given are incomplete, giving rise to assumptions, including (1) not being explained that all land must be planted with roses,

(2) Planting areas are not explained or separated."

To find out more, researchers conducted interviews with subject 1 . The following are the results of researchers' interviews with subject 1 .

$\mathrm{Q}$ : What do you do when you are asked a question like this?

S1: I first observed the problem by reading the question again and I noticed the picture

$\mathrm{Q}$ : What happens after the problem is observed?

S1: After I observed, it turns out that the information provided in the problem is incomplete, raising several questions

Q : What kind of question?

S1: The first is not explained that all land must be planted with roses, the second is not explained by the area of planting each rose or collected

Based on the results of tests and interviews with subject 1 , it appears that subject 1 has been able to check the information contained in the question, ie the information provided is incomplete.

From the results of the written test, subject 2 wrote "the question given is incomplete, so that it can lead to several assumptions as follows (1) it is not explained that all land must be planted with roses, (2) there is no mention of the planting area of each type of collection of roses or separations". And this answer is exactly the same as subject 1 . The following are the results of researchers' interviews with subject 2.

Q: What do you do when you are asked a question like this?

S1: After I reread the question, several questions emerged from me.

Q: What kind of question?

S1: The first in the problem is not mentioned that all the land must be planted with roses, the second is not mentioned planting area for each type of rose to be collected or separated so that the information in the problem is still incomplete
From the test results and researcher interviews on subject 1 and subject 2 , it can be concluded that subject 1 and subject 2 have met the indicators of critical thinking skills, namely interpretation.

\subsection{Analysis}

What is meant by analysis in this study is the analysis of problems contained in mathematical problems by linking concepts to find solutions to problems that have been faced by the subject. Based on the data collected by the researchers, both subject 1 and subject 2 answered "if it is assumed that all land must be planted, there are 2 ways to plant, namely collecting and separating". The following is a picture of the work of subject 1.

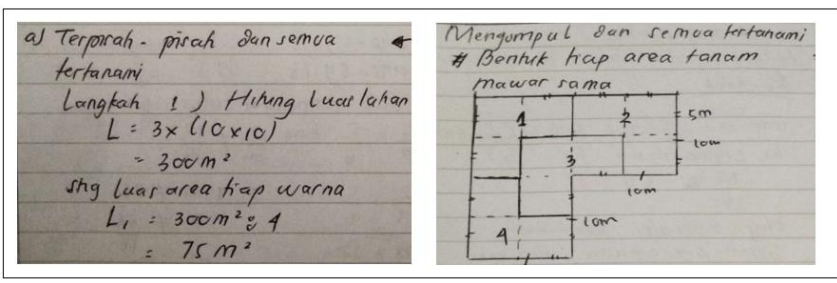

Fig. 1 Subject Work 1

The following are the results of researchers' interviews with subject 1

Q: Can you clarify the purpose of collecting and separating?

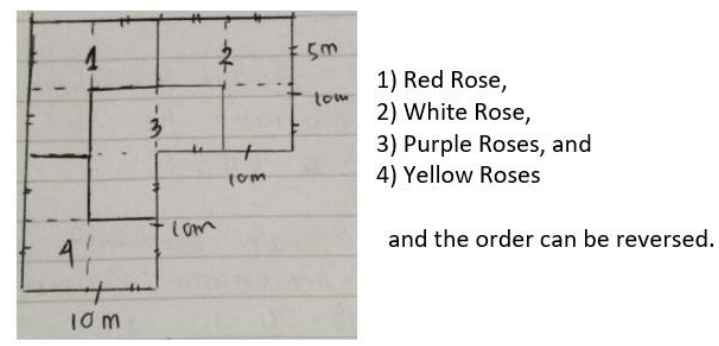

S1: If I assume all roses are planted separately, my step in working on the problem is first to calculate the area of land $\mathrm{L}=3 \times(10 \times 10)=300 \mathrm{~m}^{2}$. So the area of each color $=300: 4=75 \mathrm{~m}^{2}$

Q: What do you mean by gathering?

S1: If I consider the planted roses to be collected, that means the area is divided into 12 equal parts and then tried, so the shape of the image below.

Q: why is it divided by 12 ?

S1: because to get 3 parts of the same area, namely the size of the box, each box is $100 \mathrm{~m}^{2}$

Q: What about the 12 people? 
S1: There are 4 types of rose colors, so each square with an area of $100 \mathrm{~m} 2$ is divided into 4 parts with the same area of $25 \mathrm{~m}^{2}$. So each rose gets 3 parts of 12 squares

Based on test results and interview results, it can be concluded that subject 1 and subject 2 have mastered the concept so that they can easily get solutions in solving the problem at hand.

\subsection{Evaluation}

Evaluation can be done correctly according to subject 1 or subject 2. It can be seen from the results of their work and the results of interviews of researchers that they can evaluate the statements they made to make conclusions. For example "if it is assumed that all land must be planted, then there are 2 ways to plant, namely collecting and separating".

So it can be concluded that subject 1 and subject 2 have good accuracy in evaluating each sentence and the information contained in the problem. This is in line with what is stated by Elder and Paul (2006) that accuracy is an intellectual standard used to determine the quality of the results of reasoning in evaluating someone .

\subsection{Inference}

Based on the test results, subject 1 has a better inference than subject 2. Subject 1 gives several statements to draw conclusions from the problem in question. Subject 1 says that there are several possible answers in answering the problem in the problem. "If I assume that the roses planted are collected, it means that the field area is divided into 12 equal parts to form a square, but it can also be a right triangle." The following are the results of the work as well as the results of interviews with subject 1 .

Q: Are there other shapes besides the box?

$\mathrm{S} 1$ : Yes, that is a right triangle

Q: Can you explain why you can form a right triangle?

$\mathrm{S} 1$ : Based on 12 previously formed squares, each box can be broken into 2 right triangles so that each type of rose gets 6 equal parts with an area of $50 \mathrm{~m}^{2}$.

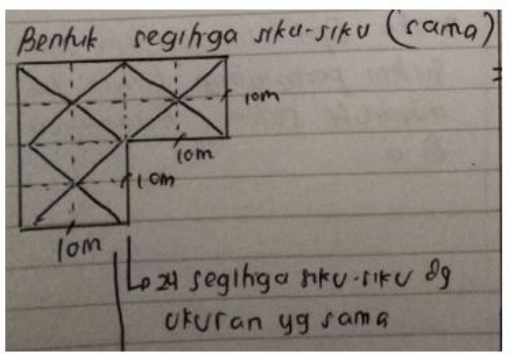

Q: Can you explain the purpose of the picture above? S1: from 12 squares formed per square can be broken into 2 right triangles, so that each rose gets 6 parts from 24 right triangles. It can also be interpreted to be able to form 12 isosceles triangles of the same size so that each rose gets 3 parts of an isosceles triangle of the same size.

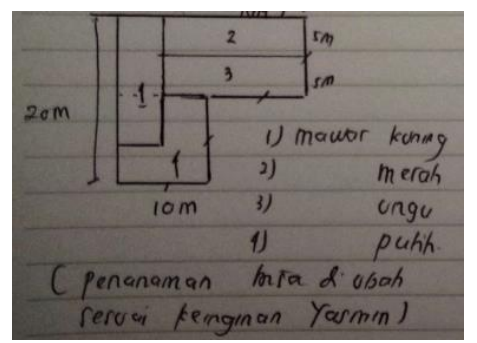

Q: Are there any other shapes besides the right triangle S1: there is, that is the shape of a free area, the land can be formed 3 rectangles consisting of a length of $15 \mathrm{~m}$ and a width of $5 \mathrm{~m}$. The most important thing is that any planting can be formed according to our wishes as long as there are no requirements in this regard.

While subject 2 is only fixated on one conclusion only. He said that if it was assumed that planting roses gathered, that meant the area was divided into 12 equal parts to form a square size. So it can be concluded that the ability of inference on subject 2 is still not good.

\subsection{Explanation}

The explanation process of the two subjects can be seen from the whole work on the results of the test and the results of the interviews conducted when the subjects were asked to explain what they had done in solving the problem with questions. Based on the data obtained shows that both subjects can present their answers well, as well as the results of interviews with both subjects who can also explain well to researchers about the results of the answers they have done.

\section{Conclusion}

The results of this study indicate that subject 1 fulfills 5 indicators of critical thinking skills, namely (1) interpretation, (2) analysis, (3) evaluation, (4) inference, and (5) explanation. Whereas subject 2 only fulfills 3 indicators of critical thinking skills, namely (1) interpretation, (2) analysis, and (3) evaluation.

Based on the results of data analysis in the results and improvement section, it can be concluded that the critical thinking ability for subject 1 is high because it meets five indicators of critical thinking ability, while the subject is classified as moderate because it only meets three indicators of critical thinking ability 
because in subject 2 the inference indicator is still not seen compared to subject 1 . That's because subject 2 only looks at problem solving from one point of view without paying attention to another point of view from which then some conclusions can be drawn.

The results of this study give researchers an idea of the critical thinking skills of students who are also a teacher. It is hoped that by knowing these conditions the researchers can design and develop learning that facilitates students to practice critical thinking skills. So when these students return to school and take over again as teachers, they can apply learning that can improve their students' critical thinking skills. Thus, students will get used to thinking critically. In addition, in learning the teacher must always involve students to think critically, give assignments containing critical thinking questions, monitor students' critical thinking skills by giving tests of critical thinking skills, then discuss them with students, so students are equipped with critical thinking skills.

\section{References}

[1] Permendikbud No. 64, "Ministerial Regulation of National Education Number 64 Year 2013 on Contents Standards of Elementary and Middle Education," vol. 2011, 2013.

[2] R. Wegerif, L. Li, and J. C. Kaufman, The routledge international handbook of research on teaching thinking. 2015.

[3] B. R. W. Paul and L. Elder, Critical Thinking: Tools for Taking Charge of Your Professional and Personal Life Critical Thinking: Tools for Taking Charge of Your Professional and Personal Life. 2002.

[4] E. Aizikovitsh-udi and D. Cheng, "Developing Critical Thinking Skills from Dispositions to Abilities: Mathematics Education from Early Childhood to High," Creat. Educ., vol. 6, no. March, pp. 455-462, 2015.

[5] Permendiknas, "Peraturan Menteri Pendidikan Nasional Republik Indonesia Nomor 22 Tahun 2006," p. 346, 2006.

[6] Permendikbud RI No. 21, "Standar Isi Pendidikan Dasar dan Menengah," Peratur. Menteri Pendidik. dan Kebud. Republik Indones. Nomor 21 Tahun 2016, 2016.

[7] P. A. Facinoe, C. A. Sanchez, N. C. Facione, and J. Gainen, "The disposition toward critical thinking," $J$. Gen. Educ., vol. 44, no. 1, pp. 1-25, 1995.

[8] P. a. Facione, "Critical Thinking: What It Is and Why It Counts," Insight Assess., no. ISBN 13: 978-1891557-07-1., pp. 1-28, 2011.

[9] R. H. Ennis, "The Nature of Critical Thinking: An Outline of Critical Thinking Dispositions," Univ. Illinois, pp. 1-8, 2011.

[10] A. R. As'ari, A. Mahmudi, and E. Nuerlaelah, "Our
Prospective Mathematic Teachers Are Not Critical Thinkers Yet," J. Math. Educ., vol. 8, no. 2, pp. 145156, 2017.

[11] N. Indrawatiningsih, Purwanto, A. R. As'Ari, Dwiyana, Sudirman, and R. Rahardi, "The ability of high school students' critical thinking in solving trigonometric problems," IOP Conf. Ser. Earth Environ. Sci., vol. 243, no. 1, 2019.

[12] A. Lewis and D. Smith, "Defining Higher Order Thinking," Theory Pract., vol. 32, no. 3, pp. 131137, 1993.

[13] C. Perkins and E. Murphy, "Identifying and measuring individual engagement in critical thinking in online discussions: An exploratory case study Development of a model," Educ. Technol. Soc., vol. 9, no. 1, pp. 298-307, 2006.

[14] E. Yackel and P. Cobb, "Sociomathematical Norms, Argumentation, and Autonomy in Mathematics," J. Res. Math. Educ., vol. 27, no. 4, p. 458, 1996.

[15] N. L. R. Stedman and B. L. Adams, "Identifying Faculty's Knowledge of Critical Thinking Concepts and Perceptions of Critical Thinking Instruction in Higher Educaiion," NACTA J., vol. 56, no. 2, pp. 914, 2012.

[16] M. Irfan, T. Nusantara, Subanji, and Sisworo, "Students know the concept but are wrong in solving the proportional problem: How did it happen?," Int. J. Sci. Math. Technol. Learn., vol. 27, no. 1, 2019.

[17] S. Sujatmika, M. Irfan, T. Ernawati, A. Wijayanti, and S. A. Widodo, "Designing E-Worksheet Based On Problem-Based Learning To Improve Critical Thinking," in ICSTI 2018, October 19-20, Yogyakarta, Indonesia, 2019, pp. 1-8. 